\title{
ANALYSIS OF POSTURAL BALANCE IN CHILDREN WHO PRACTICE AND THOSE WHO DO NOT PRACTICE SPORTS ACTIVITIES
}

Original Article

ARTIGO ORIGINAL Artículo Original

\author{
ANÁLISEDO EQUILIBRRIO POSTURAL EM CRIANÇAS PRATICANTES ENÃO PRATICANTES DE \\ ATIVIDADES ESPORTIVAS
}

ANÁLISIS DEL EQUILIBRIO POSTURAL EN NIÑOS QUE PRACTICANY NO PRACTICAN ATIVIDADES DEPORTIVAS

Eros de Oliveira Junior' 1 (D) (Physical Therapist)

Allan Felipe Mendes da Silva' (ID (Physical Education Professional)

Fabiana Dias Antunes² (DD (Physical Therapist)

Jeferson Lucas Jacinto' ${ }^{1}$ (ID (Physical Education Professional) Andreo Fernando Aguiar' (iD (Physical Education Professional)

1. Universidade Norte do Paraná (Unopar), Center for Health Sciences Research, Londrina, PR, Brazil.

2. Irmandade Santa Casa de Londrina, Londrina, PR, Brazil.

\section{Correspondence}

Jeferson Lucas Jacinto. Rua Marselha, 591, Jardim Piza, Londrina, PR, Brasil. 86041-140. jeferson1995lucas@gmail.com

\begin{abstract}
Introduction: Postural balance is essential for activities of daily living and sports performance in all life phases, but it remains unknown whether the regular practice of sports activities can improve postural balance in children. Objective:To evaluate postural balance in children who practice and those who do not practice regular sports activities. Methods: The sample consisted of 60 children (7-13 years of age) divided into two groups: participants in sports activities $(n=30)$ and non-participants in sports activities $(n=30)$. The level of physical activity was assessed by applying the Physical Activity Questionnaire for Children (PAQ-C) and static postural balance was assessed on the BIOMEC400-412 strength platform in bipedal and unipedal support. Results: No significant difference was observed between the groups in age, height or body mass index ( $p>0.05$ ). However, the groups showed a significant difference $(p<0.001)$ in the level of physical activity. The practicing sports group was characterized as active and the non-practicing group as sedentary. The practicing sports group had better postural balance in both bipedal and unipedal support compared to the non-practicing group ( $p<0.05)$. Conclusion: The practice of regular sports activities improves postural balance in children from 7 to 13 years of age. Level of evidence Il; Diagnostic study - Investigating a diagnostic test.
\end{abstract}

Keywords: Postural balance; Physical fitness; Sports; Sedentary behavior; Child.

\section{RESUMO}

Introdução: O equilíbrio postural é fundamental para as atividades da vida diária e desempenho esportivo em todas as fases da vida, mas permanece desconhecido se a prática de atividade esportiva regular pode melhorar o equilíbrio postural em crianças. Objetivo: Avaliar o equilíbrio postural em crianças praticantes e não praticantes de atividade esportiva regular. Métodos: A amostra foi composta por 60 crianças (idade: 7-13 anos), divididas em dois grupos: praticantes de atividades esportivas $(n=30)$ e não praticantes de atividades esportivas $(n=30)$. O nivel de atividade física foi avaliado com a aplicação do questionário Physical Activity Questionnaire for Children (PAQ-C) e o equilíbrio postural em condição estática foi avaliado sobre a plataforma de força BIOMEC400-412 em apoio bipodal e unipodal. Resultados: Nenhuma diferença significativa foi observada entre os grupos quanto a idade, estatura e índice de massa corporal ( $p>0,05)$. Entretanto, os grupos apresentaram diferença significativa $(p<0,001)$ quanto ao nível de atividade física; o grupo praticante de atividade esportiva foi caracterizado como ativo e o grupo não praticante como sedentário. O grupo praticante de atividade esportiva apresentou melhor equilíbrio postural tanto em apoio bipodal como unipodal, quando comparado ao grupo não praticante $(p<0,05)$. Conclusão: A prática de atividade esportiva regular melhora o equilíbrio postural em crianças de 7 a 13 anos de idade. Nível de evidência ll; Estudo diagnóstico - Investigação de um exame para diagnóstico.

Descritores: Equilíbrio postural; Aptidão física; Esportes; Comportamento sedentário; Criança.

\section{RESUMEN}

Introducción: El equilibrio postural es esencial para las actividades de la vida diaria y el rendimiento deportivo en todas las edades, pero se desconoce si las actividades deportivas regulares pueden mejorar el equilibrio postural en los niños.. Objetivo: Evaluar el equilibrio postural en niños que practican y no practican actividades deportivas habituales. Métodos: La muestra estuvo formada por 60 niños (7 a 13 años) divididos en dos grupos: practicantes de actividades deportivas $(n=30)$ y no practicantes de actividades deportivas $(n=30)$. El nivel de actividad física se evaluó mediante la aplicación del Cuestionario de Actividad Física para Niños (PAQ-C) y el equilibrio postural en condición estática se evaluó en la plataforma de fuerza BIOMEC 400-412 en soporte bípedo y unipodal. Resultados: No se observó diferencia significativa entre los grupos en cuanto a edad, talla e índice de masa corporal $(p>0.05)$. Sin embargo, los grupos mostraron una diferencia significativa $(p<0,001)$ con respecto al nivel de actividad física, el grupo que practica deporte se caracterizó como activo y el grupo no practicante como sedentario. El grupo que practica deporte presentó mejor 


\section{Descriptores: Equilibrio Postural; Aptitud física; Deportes; Conducta sedentaria; Niño.}

\section{INTRODUCTION}

Postural balance is essential for daily activities, motor development and the practice of sports activities. When inaccurate information is provided by one or more of the three sensory systems (visual, vestibular and somatosensory), postural balance can be disturbed, ${ }^{1}$ increasing the risk of falls and traumatic injuries. ${ }^{2}$ In daily life situations, the child is subjected to multiple disturbances that force them to constantly control their posture and their balance. This reality suggests reflection on the way in which children regulate postural balance and how regular sports activity could improve this variable. During static or dynamic posture, the human body uses postural strategies to maintain balance through biomechanical mechanisms and neuromuscular postural adjustments, ${ }^{3}$ such as proprioceptive information in feedback, through an already programmed system (feedforward) or using support strength (foot pressure), all intended to keep the center of mass of the body inside the support base.,4

Postural instability can occur due to increased fatigue during a motor activity, influencing the systems involved in the integration of postural control. In this way, the balance control systems perform different muscle compensations and postural adjustment strategies by activating the muscle groups of the trunk and the lower limbs in order to preserve stability and thereby decrease loss of balance and the risk of falls. Such postural balance adjustments are repeated in the execution of multiple motor skills during the practice of sports activities and, supposedly, they can contribute to improving the mechanisms and systems responsible for the stability of the body. However, the effects of the regular practice of sports activities on postural balance in children from 7 to 13 years of age remain unknown.

The objective of this study was to evaluate static postural balance in bipedal and unipedal support both in children who practice regular sports activities and children who do not. Through stabilographic analysis, a gold standard technique for assessing postural control, we tested the hypothesis that regular sports activity can improve postural balance in children

\section{METHODS}

\section{Participants}

Sixty children between the ages of 7 and 13 years were distributed into two groups: those who practice sports activities (PSA, $n=30,15$ boys and 15 girls) and those who do not practice sports activities (NPSA, $n=30$, 12 boys and 18 girls). The PSA group consisted of children who play soccer $(n=5)$, futsal $(n=8)$, rhythmic gymnastics $(n=7)$ and triathlon $(n=10)$, and all of them had been practicing these sports activities for at least 6 months. All the participants and their guardians were informed about the objectives and procedures, risks and benefits of the research and signed an Informed Consent Form approved by the Institutional Review Board of the Universidade Norte do Paraná (Unopar) as opinion number 1.810.298. All the procedures followed the1995 Helsinki Declaration.

\section{Assessment of the level of physical activity and postural balance}

The physical activity level was evaluated using the Physical Activity Questionnaire for Children (PAQ-C). ${ }^{6}$ Postural balance in static condition (bipedal and unipedal support) was evaluated on the BIOMEC400-412 strength platform (EMG System do Brasil, São José dos Campos-SP). Bioanalysis software (EMG System do Brasil, São José dos Campos-SP) was used for acquisition and treatment of the balance parameters. Postural balance parameters based on the center of pressure (COP) [COP ellipse area (in $\mathrm{cm}^{2}$ ), mean COP oscillation speed (in $\mathrm{cm} / \mathrm{s}$ ) and mean COP oscillation frequency (in $\mathrm{Hz}$ ) in the anteroposterior (AP) and mediolateral $(\mathrm{ML})$ directions of movement] were analyzed.

\section{Experimental protocol}

All participants were familiarized with the equipment and with the experimental protocol. After six minutes of rest, the participants performed the static balance test in bipedal support for 60 seconds (two attempts, with 30 seconds of rest between them) (Figure 1A). After one minute of rest, the participants performed the static test in unipedal support with the dominant lower limb for 30 seconds (three attempts, with 30-second rest periods between the attempts) (Figure 1B). The balance protocol was conducted with the participants barefoot, with arms at the sides and eyes open and focused on a target (a black circle at the height of the participant's eyes) located 2.5 meters in front of the strength platform.

\section{Statistical analysis}

Initially, the data were checked for normality using the Shapiro-Wilk test. Differences between the groups were analyzed using the Mann-Whitney test. The data are expressed as means with standard deviation (SD) and the level of significance was set at $p<0.05$. Statistical analyses were performed using SPSS version 21.0 software (IBM Corp., Armonk, N.Y., USA).

\section{RESULTS}

No significant difference was observed in the age, weight, height or BMI of the experimental groups ( $p>0.05$ ). According to the PAQ-C, the groups showed a significant difference in physical activity level $(U=70,000, p<0.001)$, with the NPSA group classified as sedentary (score 2.91) and the PSA group as active (score 4.13) (Table 1). Regarding the postural balance results, the PSA group performed better than the

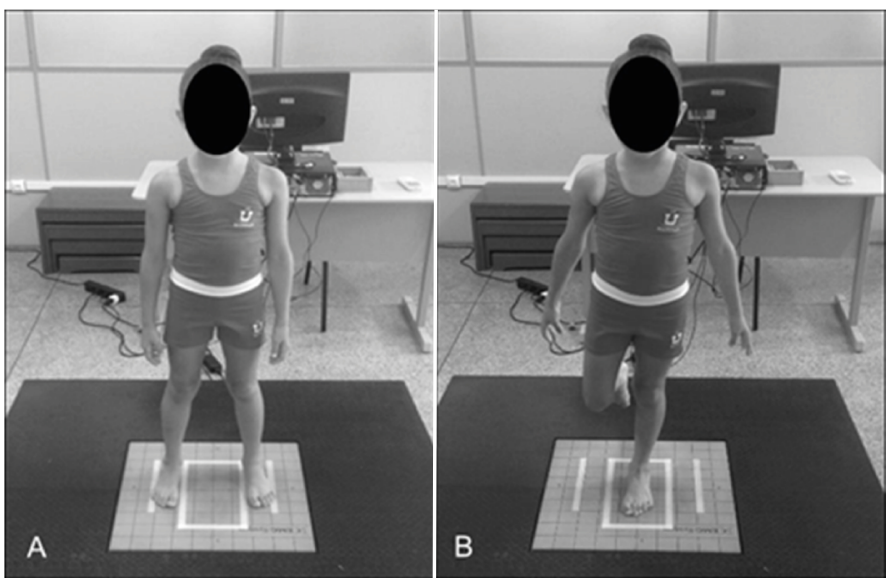

Figure 1. (A) Balance test in bipedal support, (B) Balance test in unipedal support. Source: the author. 
NPSA group in the bipedal support test (COP $[U=200,500, p<0.001]$; anteroposterior velocity $[\mathrm{U}=32,500, p<0.001]$; mediolateral velocity [U $=39,500, p<0.001]$; anteroposterior frequency $[U=186,000, p<0.001]$; mediolateral frequency $[U=271,000, p=0.008]$ ) (Table 2), and in the unipedal support test (COP [U =277,000, $p=0.011]$; anteroposterior velocity $[U=283,500, p=0.014]$; mediolateral velocity $[U=247,500, p=0.003]$; anteroposterior frequency $[U=205,500 ; p<0.001]$; mediolateral frequency $[U=276,500 ; p=0.010]$ ) (Table 3).

Table 1. Characteristics of the participants.

\begin{tabular}{c|c|c|c}
\hline & PSA $(\mathbf{n}=\mathbf{3 0})$ & NPSA $(\mathbf{n}=\mathbf{3 0})$ & $\mathbf{p}$-value \\
\hline Age (years) & $11.03(2.34)$ & $10.83(1.58)$ & 0.29 \\
\hline Weight $(\mathrm{kg})$ & $43.19(14.22)$ & $41.15(17.00)$ & 0.51 \\
\hline Height $(\mathrm{cm})$ & $145(14)$ & $142(10)$ & 0.13 \\
\hline BMl $\left(\mathrm{kg} / \mathrm{m}^{2}\right)$ & $19.40(3.62)$ & $21.18(5.47)$ & 0.33 \\
\hline PAQ-C score & $4.13(0.58)$ & $2.91(0.62)$ & $<0.001^{*}$ \\
\hline
\end{tabular}

PSA: practice sports activities, NPSA: do not practice sports activities, BMI: body mass index. Values expressed as mean and standard deviation (SD). * ${ }^{*}$ evel of significance $p<0.05$.

Table 2. Balance based on COP for the bipedal test.

\begin{tabular}{c|c|c|c}
\hline Balance in bipedal support & PSA $(\mathbf{n}=\mathbf{3 0})$ & NPSA $(\mathbf{n}=\mathbf{3 0})$ & p-value \\
\hline Area of the ellipse $\left(\mathrm{cm}^{2}\right)$ & $2.27(1.59)$ & $4.05(2.38)$ & $<0.001^{*}$ \\
\hline Velocity $(\mathrm{cm} / \mathrm{s})$ & & & \\
\hline AP & $1.18(0.53)$ & $2.94(1.48)$ & $<0.001^{*}$ \\
\hline ML & $1.09(0.57)$ & $3.19(2.74)$ & $<0.001^{*}$ \\
\hline Frequency $(\mathrm{Hz})$ & & & \\
\hline AP & $0.32(0.10)$ & $0.58(0.28)$ & $<0.001^{*}$ \\
\hline MLA: practice sports activities, NPSA:do not practice sports activities, COP:center of pressure, AP:anteroposterior,
\end{tabular}

ML: mediolateral. Values expressed as mean and standard deviation (SD). *Level of significance $p<0.05$.

Table 3. Balance based on COP in unipedal test.

\begin{tabular}{c|c|c|c}
\hline Balance in unipedal support & PSA $(\mathbf{n}=\mathbf{3 0})$ & NPSA $(\mathbf{n}=\mathbf{3 0})$ & p-value \\
\hline Area of ellipse $\left(\mathrm{cm}^{2}\right)$ & $9.80(2.84)$ & $14.22(7.85)$ & $0.011^{*}$ \\
\hline Velocity $(\mathrm{cm} / \mathrm{s})$ & & & \\
\hline AP & $4.02(1.67)$ & $5.16(2.41)$ & $0.014^{*}$ \\
\hline ML & $3.83(1.22)$ & $5.06(2.48)$ & $0.003^{*}$ \\
\hline Frequency $(\mathrm{Hz})$ & & & \\
\hline AP & $0.69(0.20)$ & $0.93(0.26)$ & $<0.001^{*}$ \\
\hline ML & $0.87(0.19)$ & $1.03(0.25)$ & $0.010^{*}$ \\
\hline
\end{tabular}

(SOP. center of pressure ML: mediolateral. Values expressed as mean and standard deviation (SD). * Level of significance $p<0.05$.

\section{DISCUSSION}

The results of this study demonstrated that the group of children who practice sports activities has better balance control than the group of non-practicing and insufficiently active children. The children in the group who practiced sports activities participated in extracurricular activities in which they developed specific team or individual sports skills. Our results are consistent with those of the study by Rabello et al.' who reported that young taekwondo athletes had better postural control (COP velocity during unipedal support) when compared to sedentary youths. In addition, Greco et al. ${ }^{8}$ stress the importance of regular practice of extracurricular sports activities, showing that an eight-week training program in combination with the practice of physical education at school improved the static balance, the flexibility of the lower limbs, leg strength and overall motor coordination in children aged 8 to 10 years. On the other hand, the children who only participated in physical education at school did not show significant improvement in the static balance and strength of the lower limbs. Such evidence, together with our findings, suggests that the regular practice of extracurricular sports activities may be an important strategy to reduce sedentary behavior and, thus, improve the level of physical fitness, overall motor coordination and postural balance in children. ${ }^{9}$
Improvement of postural balance in response to the practice of sports activities may be related to the repetition of specific techniques and movements, developing skills that accelerate the development of the vestibular system, which promotes balance. In addition, sports training can increase the ability to use somatosensory information, also resulting in improved postural balance. ${ }^{10,11}$ The study by Heleno et al. ${ }^{12}$ showed that a five-week sensory-motor training program, with static and dynamic exercises associated with soccer movements, improved the functional performance and postural control of young soccer players. These findings corroborate the evidence that the practice of sports activities can increase physical fitness and decrease the fatigue parameters that are critical for postural balance. ${ }^{13,14}$ In fact, active and trained individuals are less affected by physiological effects of fatigue and by disturbances of the proprioceptive system, helping the nervous system to better control postural balance, ${ }^{5,15-18}$ as evidenced in the study by Pau et al., ${ }^{19}$ in which adolescent soccer players had less fatigue after exercise, with improved capacity for postural balance. On the other hand, insufficiently active individuals demonstrate a more pronounced effect from fatigue on postural balance and they require a longer recovery time to return to baseline postural performance. ${ }^{2}$

Other studies have shown that better physical fitness in children and adolescents is associated with better postural balance. ${ }^{19,20}$ Stanek et al..$^{21}$ showed that children who participated in sports activities had better postural balance than insufficiently active children. In addition, Foweather et al. (2008) ${ }^{22}$ reported that a nine-week sports activity program for 8- to 9-year-old children significantly improved their static postural balance. Neuromuscular performance is more striking in this age group, providing greater motor skills, which allows children to improve the execution of specific motor tasks, such as postural adjustment. ${ }^{23}$ Granacher et al. ${ }^{24}$ found that traditional balance training programs three times a week for four weeks only resulted in a small to medium effect on postural balance ability in children from 6 to 7 years of age. The authors state that the incomplete neuromuscular maturity of the postural control system in children at this age probably explains their findings. Moreover, the visual and vestibular afferent systems attain superior performance only around adolescence. ${ }^{25}$ Nevertheless, our findings show that regular sports practice can contribute to improving postural balance starting at age 7 .

Studies report that the age of 7 to 8 years is fundamental to postural development, since in this phase children may have greater difficulty maintaining balance. ${ }^{26,27}$ Conscious concentration on the task being performed is fundamental in planning movement. As a result of good movement planning, the body can adapt to each activity encountered. If the child has this ability, they will be able to control their static and dynamic balance without needing additional outside help. ${ }^{28}$ In the study by Faigenbaum et al. ${ }^{23}$ with 7-year-old children, postural balance was preserved during the children's participation in sports activities. However, after an eight-week interruption in the activities, the children's postural balance regressed to baseline. Because the response of postural oscillation to exercise depends on its type, intensity and duration, and the capacity of neuromuscular skills (such as postural balance) is necessary to perform a repeated movement, any period of detraining from a specific practice can reduce the transmission of the stimulus to the neuromuscular system, decreasing postural balance ${ }^{23}$. The fatigue of stabilizer muscles (such as the gastrocnemius, soleus and lumbar muscles) impairs the correct alignment of the stabilizer joint and reduces neuromuscular control around the joints, which promotes compromised postural stability. ${ }^{29,30}$ Thus, to maintain or improve postural balance and reduce the risk of falls and future injuries, specific balance exercises should be combined with activities that improve overall physical fitness and the sensory system. ${ }^{2}$

This study has some limitations. We only recruited children who play soccer, futsal, rhythmic gymnastics and triathlon. To expand the external validity 
of the results, further studies are needed to investigate the possible effects of the practice of other sports on children's postural control. In addition, our results should be interpreted with caution, due to the reduced sample size and the lack of evaluation of the state of neuromuscular maturity of the children. not practice sports activities and are insufficiently active. Thus, the practice of sports activities, with emphasis on sensory integration and postural balance, should be widely encouraged both in school and extracurricular contexts.

\section{CONCLUSION}

Children who practice regular sports activities and are physically active have better postural balance than children who do

All authors declare no potential conflict of interest related to this article

AUTHORS' CONTRIBUTIONS: Each author made significant individual contributions to this manuscript. EOJ: preparation of the research project, statistical analysis and writing; AFMS: data collection, tabulation of the data and writing; FDA: preparation of the research project, statistical analysis and writing; Uப: statistical analysis, writing and review; AFA: preparation of the research project, writing and review of the article.

\section{REFERENCES}

1. Hohne A, Stark C, Bruggemann GP, Arampatzis A. Effects of reduced plantar cutaneous afferent feedback on locomotor adjustments in dynamic stability during perturbed walking. J Biomech. 2011;44(12):2194-200.

2. Steinberg N, Nemet D, Pantanowitz M, Zeev A, Hallumi M, Sindiani M, et al. Longitudinal study evaluating postural balance of young athletes. Percept Mot Skills. 2016;122(1):256-79.

3. Winter DA. Human balance and posture control during standing and walking. Gait \& Posture. 1995;3(4):193-214

4. Pollock AS, Durward BR, Rowe PJ, Paul JP. What is balance? Clin Rehabil. 2000;14(4):402-6.

5. Gribble PA, Hertel J, Denegar CR, Buckley WE. The effects of fatigue and chronic ankle instability on dynamic postural control. J Athl Train. 2004;39(4):321-9.

6. Guedes DP, Lopes CC, Guedes JERP. Reprodutibilidade e validade do Questionário Internacional de Atividade Física em Adolescentes. Rev Bras Med Esporte. 2005;11(2):151-8.

7. Rabello LM, Macedo CdSG, Gil AW, Oliveira MRd, Coelho VA, Silva GB, et al. Comparison of postural balance between professional tae kwon do athletes and young adults. Fisioter Pesq. 2014;21 (2):139-43

8. Greco G, Cataldi S, Fischetti F. Effectiveness of a short after-school intervention on physical fitness in school-aged children. Ricerche di Pedagogia e Didattica, Journal of Theories and Research in Education. 2019;14(1):22.

9. Cattuzzo MT, dos Santos HR, Ré AHN, de Oliveira IS, Melo BM, de Sousa Moura M, et al. Motor competence and health related physical fitness in youth: A systematic review. J Sci Med Sport. 2016;19(2):123-9.

10. Shirabe NA, Silva RAd, Oliveira MR, Nowotny AH, Sturion LA, Gil AWdO, et al. Atletas de taekwondo têm melhor controle postural do que atletas de handebol e futebol americano. Rev Bras Med Esporte. 2017;23(6):473-6.

11. Paillard T, Noe F, Riviere T, Marion V, Montoya R, Dupui P. Postural performance and strategy in the unipedal stance of soccer players at different levels of competition. J Athl Train. 2006:41(2):172-6.

12. Heleno LR, da Silva RA, Shigaki L, Araújo CGA, Coelho Candido CR, Okazaki VHA, et al. Five-week sensory motor training program improves functional performance and postural control in young male soccer players - A blind randomized clinical trial. Phys Ther Sport. 2016;22:74-80.

13. Zemkova E, Hamar D. Physiological mechanisms of post-exercise balance impairment. Sports Med. 2014;44(4):437-48

14. Kita I, Imanaka $\mathrm{K}$, Arita $\mathrm{H}$. Effects of practice on cardiorespiratory responses during postural control. Exp Brain Res. 2005;161(4):512-8

15. Pau M, Ibba G, Leban B, Scorcu M. Characterization of static balance abilities in elite soccer players by playing position and age. Res Sports Med. 2014;22(4):355-67.
16. Zemková E, Hamar D. Postural sway response to exercise: The effect of intensity and duration. International Journal of Applied Sports Sciences. 2005;17:1-6.

17. Wilkins JC, Valovich McLeod TC, Perrin DH, Gansneder BM. Performance on the balance error scoring system decreases after fatigue. J Athl Train. 2004;39(2):156-61.

18. Wisloff U, Castagna C, Helgerud J, Jones R, Hoff J. Strong correlation of maximal squat strength with sprint performance and vertical jump height in elite soccer players. Br J Sports Med. 2004;38(3):285-8.

19. Pau M, Ibba G, Attene G. Fatigue-induced balance impairment in young soccer players. J Athl Train. 2014:49(4):454-61.

20. Burgi F, Meyer U, Granacher U, Schindler C, Marques-Vidal P, Kriemler S, et al. Relationship of physica activity with motor skills, aerobic fitness and body fat in preschool children: a cross-sectional and longitudinal study (Ballabeina). Int J Obes (Lond). 2011;35(7):937-44.

21. Stanek E, Truszczynska-Baszak A, Drzał-Grabiec J, Tarnowski A. Postural balance assessment in children aged 7 to 9 years, as related to body weight, height, and physical activity. Biomedical Human Kinetics. 2015;7(1).

22. Foweather L, McWhannell N, Henaghan J, Lees A, Stratton G, Batterham AM. Effect of a 9-wk. after-school multiskills club on fundamental movement skill proficiency in 8- to 9-yr--old children: an exploratory trial. Percept Mot Skills. 2008;106(3):745-54

23. Faigenbaum AD, Farrell AC, Fabiano M, Radler TA, Naclerio F, Ratamess NA, et al. Effects of detraining on fitness performance in 7-year-old children. J Strength Cond Res. 2013;27(2):323-30.

24. Granacher U, Muehlbauer T, Maestrini L, Zahner L, Gollhofer A. Can balance training promote balance and strength in prepubertal children? J Strength Cond Res. 2011;25(6):1759-66.

25. Steindl R, Kunz K, Schrott-Fischer A, Scholtz AW. Effect of age and sex on maturation of sensory systems and balance control. Dev Med Child Neurol. 2006:48(6):477-82.

26. Roncesvalles MN, Schmitz C, Zedka M, Assaiante C, Woollacott M. From egocentric to exocentric spatial orientation: development of posture control in bimanual and trunk inclination tasks. J Mot Behav. 2005;37(5):404-16

27. Nougier V, Bard C, Fleury M, Teasdale N. Contribution of central and peripheral vision to the regulation of stance: developmental aspects. J Exp Child Psychol. 1998;68(3):202-15.

28. Melzer I, Benjuya N, Kaplanski J. Age-related changes of postural control: effect of cognitive tasks. Gerontology. 2001;47(4):189-94

29. Cetin N, Bayramoğlu M, Aytar A, Surenkok O, Yemisci O. Effects of lower-extremity and trunk muscle fatigue on balance. Open Sports Medicine J. 2008;2:16-22

30. Armstrong W, Yaggie J. Effects of lower extremity fatigue on indices of balance. Human Kinetics Journal. 2003;13(4):312-22. 